\begin{tabular}{lc|}
\hline UDJES (Ahmad Dahlan Journal of English Studies) \\
VOL 8, No. 1,32-45 \\
$\begin{array}{l}\text { Universitas } \\
\text { Ahmad Dahlan }\end{array}$ \\
https://doi.org/10.26555/adjes.v8i1.20052
\end{tabular}

\title{
Washback of Microteaching Test on EFL Students' Overseas Teaching Practice
}

\author{
${ }^{1}$ Fitrie Amaelia, ${ }^{2}$ Entika Fani Prastikawati \\ Email : 1fitriamelia@gmail.com, 2entikafani@upgris.ac.id \\ 1,2 Universitas PGRI Semarang, Indonesia
}

\section{ARTICLE INFO}

\section{Article history}

Received: 16 February 2021

Revised: 9 March 2021

Accepted: 10 March 2021

Keywords

washback

microteaching test

overseas teaching practice

\section{ABSTRACT}

This research aim was to investigate the washback of microteaching test on EFL students' overseas teaching practice by presenting two main data on the influence of microteaching test on EFL students' overseas teaching practice, and the contribution of microteaching test on EFL students' overseas teaching practice. This research applied descriptive qualitative research design by distributing a questionnaire and followed by a semi-structured interview. The subjects of the research were ten EFL students who had contributed to overseas teaching practice. The research revealed two main results. The result showed that most of the respondents $(80 \%)$ agreed that the microteaching test had a significant influence on their teaching practice in terms of teaching and learning process, their teaching skills, their confidence, and reduced anxiety and fear. Further, the microteaching test was revealed for having a crucial contribution to their teaching practice. It also was supported by the detailed finding that those contributions were managing a classroom, selecting teaching goals and lesson plans, increasing the speaking ability, delivering the teaching materials, and managing time effectively.

This is an open access article under the CC-BY-SA license.

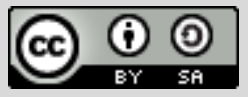

\section{Introduction}

Education is the oldest concept in history, which dates back to ancient times and reaches today. Societies that existed since the creation of the world until today maintained their existence by transferring the values they created to new generations. Education is defined as the studies conducted to develop the main and body, emotional and social skills, and behaviors in the most appropriate or desire direction (Saban \& Çoklar, 2013). In analyzing or developing education among people, there is a process which is called teaching and learning.

In teaching, we need the process of education to transfer knowledge. Teaching is a profession that requires specialized knowledge and skills in which the teacher should be given special training before starting their profession (Kilic, 2010). Based on that argument, it can be concluded that teaching is the process of transferring knowledge. According to Aglazor (2017) 
said while teaching is defined as a compulsory course for all aspiring student teachers registered in teacher preparation programs. It transfers the knowledge by teachers to students using educational tools in an organized and regular manner, generally at a teaching institution. It means that education is the process of transferring knowledge. Indrawati (2018) said that the purpose of teaching is not only to pass the test but also for preparing students in facing globalization to the higher steps of education. Thus, the purpose of education is to develop the knowledge and skills of individuals for their adaptation to the society they are in. Individuals need to be educated in a way that they can affect contemporary developments. This is only possible with a good educational system and a qualified teaching staff (Saban \& Çoklar, 2013).

Universitas PGRI Semarang (UPGRIS) is a university that develops education and teaching methodologies. One of the departments is the English Education Department. Therefore, UPGRIS has been concerned and focused to prepare the teachers' candidates for being teachers (Prastikawati \& Asropah, 2020). In the process of preparing the students to be professional teachers, there is a teaching practice or commonly called an internship that is divided into internship 1, internship 2, and internship 3. Teaching practice is an important component of becoming a teacher. During the teaching practice, student-teacher is allowed to try the art of teaching before actually getting a real-world of the teaching profession (Kiggundu \& Nayimuli, 2009).

In internship 1, the main focus is on the school's physical observation. Meanwhile, internship 2 is dedicated to curriculum observation such as syllabus, lesson plan, and the curriculum that the school used, particularly the lesson plans the teachers used to teach in the classroom. As the continuity of internship 1 and internship 2, internship 3 aims at exploring the students' ability to teach in a real English classroom. This means that the students are directly deployed in schools to teach in the classroom based on the curriculum by using lesson plans as well as adjusting it with the syllabus that the school used. This study focuses on Internship 3 where the main subject is the microteaching test of teaching practice.

The internship 3 is divided into 2 programs, namely internship in Indonesia (magang dalam negeri) and overseas internship. English Education Department becomes one of the departments that facilitates the students to have an overseas internship. The overseas internship aims to give the students experience and prepare them to compete with the other countries in the world in the case of education development that happens recently. The overseas internship exchanges the experience and gives them the chance to learn about teaching and education from different parts of the world, particularly in Southeast Asia. The aims are in line with the vision and mission of the English Education Department. To apply for an overseas internship, these students should pass a microteaching test which is held by the university. As we know that to be eligible for a 
teaching practice program, the students must pass the microteaching test.

The microteaching test assesses the students both in terms of their English and teaching competence, to determine if they are ready to practice teaching overseas. Microteaching is a teacher training technique first developed by Dwight W. Allen and his colleagues at Stanford University in 1963. Microteaching is a strategy that can be applied at various pre-service and inservice stages in the professional development of teachers (Abakay et al., 2016). Microteaching test is mainly on the practice of teaching in which several numbers of learners are involved. The thinking behind itis that pre-service teacher should be guided to practice with a smaller number which may be gradually increased as his/her competences increases (Arsal, 2015). The students' teacher training procedure is geared toward simplification of the complexities of the regular teaching-learning process (He \& Yan, 2011). Class size, time, task, and content is scaled down to provide optimal training environments. The supervisor/mentor demonstrates a certain teaching skill to be practiced. This may be a live demonstration or a video presentation of the skill. Then, the group members select a topic and prepare a lesson of 10-15 minutes (Ping, 2013). In this case, the microteaching test is a simulated teaching session self-learning tool, involving a small number of students, observer/supervisor and teaching a small or single concept in a short time and concentrates on a specific teaching skill (Dhananjaya \& Nusrath, 2018) Research done by Ismail (2011) concluded that the benefit of the microteaching test is the study gives the impact of microteaching experience on the views of prospective teachers pre-service education program.

Nevertheless, the test is still needed in the educational program not only to inform the student's achievement but also to transform the students' attitude and competence (Tirtaningrum \& Ngadiman, 2015). The test is not deniable at the end. A test is a method to determine a student's ability to complete certain tasks or demonstrate mastery of skill or knowledge of content. Some types would be multiple-choice tests or a weekly spelling test. In the fields of education and applied linguistics, it is widely believed that testing influences teaching and learning (Prastikawati et al., 2016; Safa \& Goodarzi, 2014).

The test itself is closely related to the assessment process. An assessment is an ongoing process that encompasses a much wider domain. Assessment can occur anytime, and the students sometimes do not know that their performance is measured (Jabbarifar et al., 2019; Prastikawati et al., 2020). The term assessment is well considered as a tool for evaluating, measuring, and recording the students' academic readiness, students' learning progress, and students' acquisition (Abakay et al., 2016; Ali \& Hamid, 2020; Zhao, 2014). The main goal of an assessment is to gain information on students' learning progress and to improve the teaching quality of teachers. This balancing process in the teaching and learning process assesses as an ongoing process arising out of teaching and learning interaction (Caner, 2010; Wiyaka et al., 
2020).

According to (Fatonah et al., 2013), there are three kinds of assessment, namely assessment for learning (formative), assessment of learning (summative) and assessment as learning (self and peer assessment). Based on that opinion, an assessment is not only to measure the learning process and learning outcomes, but it is also to improve the learning process, motivate students, and diagnose students' weaknesses. To add, assessment for learning is implemented correctly in the learning process and used to assess anything related to the learning process, including to facilitate students to learn (Hung \& Huang, 2019; Kuang, 2020; Thi \& Hoa, 2020; Wiyaka et al., 2016).

Therefore, the role of washback was proven to have positive washback effects as students were motivated well to learn and give their best value on the test (Cholis \& Rizqi, 2018; Dong, 2020; Sumardi, 2017). Washback is the effect of testing on teaching and learning otherwise known among language testing specialists as washback. In large scale assessment, washback generally refers to the effects the tests have on instruction in terms of how students prepare for the test (Beikmahdavi, 2016; Brown, 2004; Djurić, 2015; Hughes, 2003; Muñoz, 2017). Further, the research on washback is determined as an empirical study because it is related to the actual experiences and activities of the teachers and the students in the classroom. Washback of a test is worth studying since it inevitably occurs and affects teachers and students in a myriad of ways (Sundayana et al., 2018). While the previous research highlighted on the washback of some large-scale standardized test such as TOEFL test, IELTS test, and National Examinations, none of the research revealed the washback of microteaching test on EFL students' overseas teaching practice. Therefore, this research tries to fill the gaps by investigating the washback of microteaching test on ELF students in the context of overseas teaching practice classroom in the university level.

\section{Method}

This research applied qualitative research as the research design. Since the data of the research served in the form of words and not in the form of a number, it belongs to qualitative research. Katz (2015) stated "qualitative methodology" as the procedure research that produces descriptive data in the form of words written or spoken of the people and behaviors that can be observed. In this research, the researcher took the data to get the information before analyzing it.

The subjects in this research were ten English Department students' of Universitas PGRI Semarang who did their teaching practice overseas. Those ten English department students were chosen because they were all the English department students who did overseas teaching practice in Malaysia, Philiphines, and Vietnam. In collecting the data, the researcher used some 
instruments; a questionnaire and a semi-structured interview. As stated by Sugiyono (2015), in qualitative research, the main technique in collecting data is participant observation, deep interview, document analysis, and triangulation. The explanations are as follows:

\section{Questionnaire}

This common type of instrument that is used by the researcher to collect the data. A questionnaire is basically a set of questions related to some topics which have to be fulfilled by the object of the research in order to get the data. In line with Kothari (2004), a questionnaire consists of several questions printed or typed in a definite order on a form or set of forms. As we know, kinds of the questionnaire are divided into two different parts which are open questionnaires and close questionnaires. In this study, the researchers tended to use the closedended questionnaire to limit the scope of the research. Hence, the study of the research are in line and be focused on what is being discussed. Kothari then describes the difference in the form of a questionnaire.

In this study, the researcher took the closed-ended questionnaire. A closed-ended questionnaire is a closed-question or the questionnaire in which the respondents need to put their answer in the questionnaire with provided answer (Sukardi, 2003). This questionnaire consisted eleven questions with five Likert scales that focused on the questions on the washback of a microteaching test, including the influence and the contribution of the microteaching test on English Department students' overseas teaching practice. This questionnaire is divided into two main themes. The first, the questionnaire is to find out the influences of a microteaching test. The second is to find out how the contribution of a microteaching test. An inter-rater approach was applied to ensure the validity of this closed-ended questionnaire. There were two experts of assessment from two different universities provided some suggestions on the questionnaire. After making some improvements, the closed-ended questionnaire was validated by these two assessment experts. Furthermore, Cronbach's Alpha Test was used to measure the reliability of the closed-ended questionnaire. Using SPSS, the reliability of the close-ended questionnaire is .76 that shows a high level of consistency.

\section{Interview}

The interview that had been given by the researcher to the respondents was the semistructured interview which aimed to support and clarify the answer of the closed-ended questionnaire. First, the respondents answered the closed-ended questionnaire. After the respondents finished answering a questionnaire, the researcher interviewed the respondents. Based on the interview the respondents clarified the answer of the effect of the microteaching test. Further, Kvale (1996:14) in (Cohen et al., 2007) remarks an interview as an interchange of views between two or more people on a topic of mutual interest, sees the centrality of human 
interaction for knowledge production and emphasizes the social situatedness of research data. In this research, the researcher asked some questions related to microteaching tests to the studentteacher who conducted overseas teaching practice.

After collecting all the data needed from a closed-questionnaire, the researcher analyzed it in the form of percentages and figures and clarified them. Further, the qualitative data were analyzed descriptively to support the data from a closed-questionnaire.

\section{Discussion}

The finding of this research is divided into two parts. The first part deals with the influence of microteaching test on the English Department students' teaching practice overseas. The second one deals with the contribution of microteaching test to English Department students' teaching practice overseas.

1. The Influence of Microteaching Test on English Department Students' Overseas Teaching Practice in Universitas PGRI Semarang

To collect the data regarding the influence of microteaching test on English students' overseas teaching practice in Universitas PGRI Semarang, the researcher gave questionnaires to the respondents about the influence of the microteaching test on English Department students' overseas teaching practice. The result of the questionnaire will reveal the exact data on how microteaching test influenced English Department students' overseas teaching practice.

The findings data were based on close-ended questionnaires, then the data were supported by a semi interview to clarify the answers of the questionnaires that had been given to the respondents. Based on the close-ended questionnaire given to ten respondents, the result shows that the microteaching test had a significant influence on the English department students' overseas teaching practice. The finding of the closed-ended questionnaire 1 (CQ1) showed that the microteaching test influenced the student-teacher teaching practice overseas. The result of the CQ1 showed that there is a great impact of the microteaching test. The figure 1 shows the result:

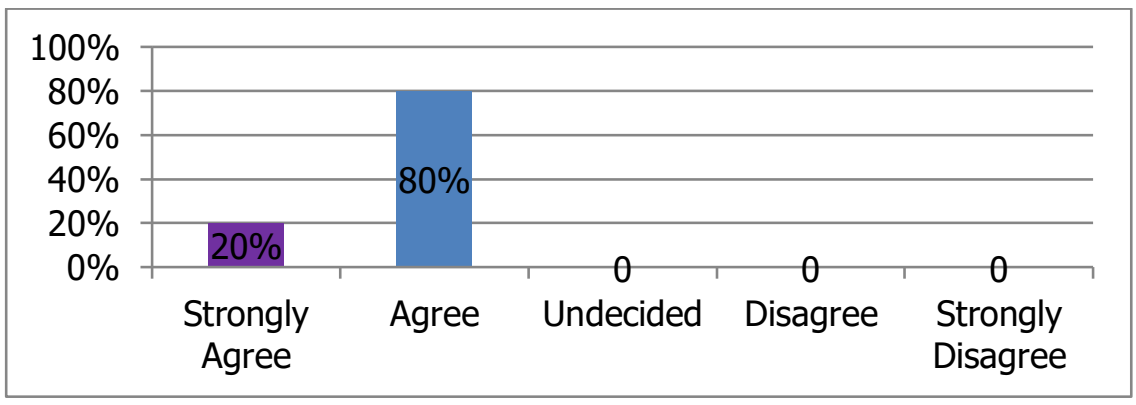

Figure 1. Students' overseas teaching practice belief on the influence of microteaching test

The finding on figure 1 showed that $80 \%$ of the ten respondents agreed that the 
microteaching test influenced the students' overseas teaching practice. Then, $20 \%$ of the respondents strongly agreed that the microteaching test influenced them. It can be concluded that all the ten respondents agreed that the microteaching test influenced the students' overseas teaching practice. Effect of microteaching on pre-service students was also studied by other researchers (Bakir, 2014; Onwuagboke et al., 2017; Wangchuk, 2019). Their findings revealed that microteaching test was good for students' quality improvement.

Concerning how the microteaching test influenced the students' overseas teaching practice. The result of the questionnaires also showed detailed data about the area of the influenced microteaching test. It revealed that microteaching tests also influenced English Department students' overseas teaching practice in the areas of student-teacher learning, teaching skills, students' confidence development, and anxiety and fear decrease. This finding was supported by the result of CQ2, CQ3, CQ4, and CQ5. The graph below shows the details of that result.

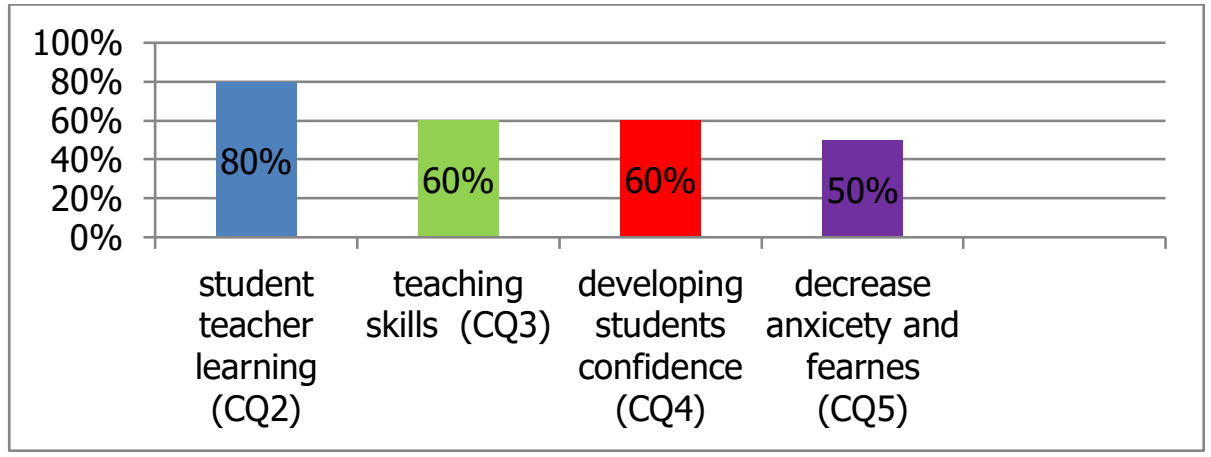

Figure 2. The influence of microteaching test

Figure 2 above shows $80 \%$ of the respondents stated that microteaching test influenced them in their students' teacher learning. Microteaching is organized to help students know a teaching and learning situation. There, students can learn effective teaching methods and strategies to their pupils. Moreover, they can gain knowledge about competencies needed in having effective classroom activities (Ike, 2017). Meanwhile, 60\% of respondents agreed that a microteaching test influenced them in teaching skills and developing students' confidence. As stated by Onwuagboke et al. (2017) that some benefits of microteaching are students gain more confidence and some supports. They can make some trials on what to prepare before teaching and how to deal with their teaching plans. So that, they will not get confused when they are doing a teaching practice then. Through microteaching, students' improvement of confidence enable them to have good and effective classroom organization (Wangchuk, 2019). Furthermore, 50\% of respondents agreed that the microteaching test helped them lower their anxiety and fear. For some students, they may be insecure on their teaching competence and teaching materials mastery. They are afraid of not being able to gain the students' attention or making students not able to get the points of what they are delivering in the class. Therefore, they need some 
practices like microteaching to give them some teaching experiences by teaching their peers and to make them braver.

The finding on figure 2 is also in line with what the researchers found in the semi-structured interviews relating to the influence of a microteaching test in student-teacher learning process, students' teaching skills, students' confidence in delivering material, and the students' anxiety and fear. Some excerpts were presented as follow:

"The microteaching test is important and influenced me because I was challenged to find out the most suitable way to teach in certain topics/materials, and it influenced the way of teaching-learning."(R3)

"Microteaching test actually has very good impact on me especially because microteaching test is like a simulation for us, we teach actual in the reality because by this one we will become prepared". (R1)

"I think the current microteaching test gives me positive aspect because it can improve my skill in teaching practice."(R2)

"It makes me be more prepared and gives me more confidence to face the teaching practice especially overseas."(R1)

"I think I will be more confident in doing teaching practice and help me deal with anxiety and fear in teaching."(R4)

As a result, microteaching test brings about good impact on students who are going to join a teaching practice. It significantly has a vital role in the process of preparing students for real teaching setting (Uzun, 2012). At this time, they will do some experiments on classroom matters such as teaching strategies, methods, media, and so on, which enable them to know whether their teaching ways are efficient or not (Remesh, 2013). Consequently, their teaching ability is getting better.

\section{The Contribution of Microteaching Test on English Department Students' Overseas}

\section{Teaching Practice in Universitas PGRI Semarang}

To find out the data about microteaching test contribution on English students' overseas teaching practice in Universitas PGRI Semarang, the researchers gave questionnaires to the respondents regarding the contribution of the microteaching test on English Department students' overseas teaching practice. The result of the questionnaire will reveal specifically how microteaching test contributed to English Department students' overseas teaching practice. The finding showed that the microteaching test had a significant contribution to the English department students' overseas teaching practice. The result which was answered by the closedended questionnaire 11 (CQ11) showed that the microteaching test contributed to the students overseas teaching practice. The results are as follows: 


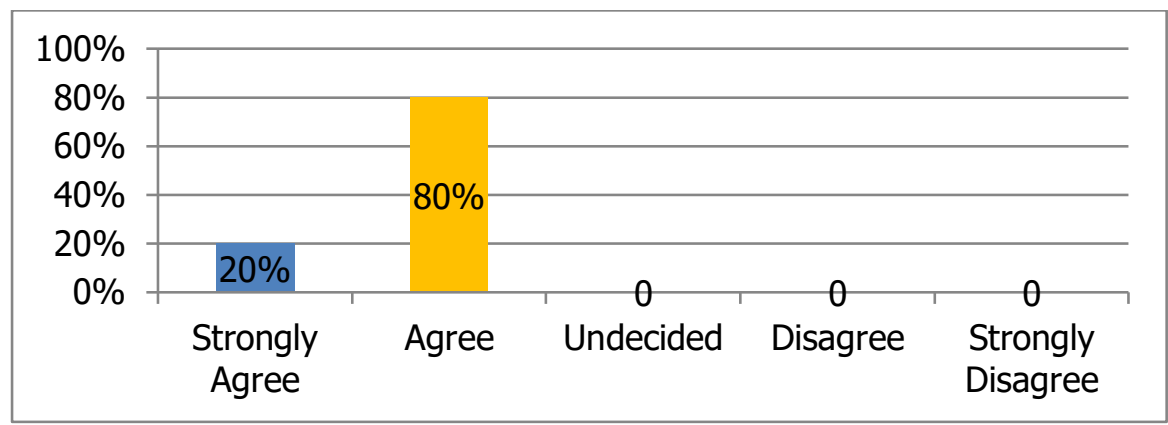

Figure 3. The students' overseas teaching practice belief regarding the contribution of the microteaching test

The result of the CQ11 on figure 3 showed that the microteaching test gave a significant contribution to the students during their teaching practice overseas. A total of $80 \%$ of the ten respondents agreed that the microteaching test provided a fundamental contribution to the students' overseas teaching practice. Then, $20 \%$ of the ten respondents strongly agreed that the microteaching test contributed to the students' overseas teaching practice. It can be concluded that all the respondents agreed that the microteaching test has immensely helped them. The finding above is shown in the percentage of the result.

In addition, a microteaching test had contributed to English Department students' overseas teaching practice in the area of classroom management, teaching goals and lesson plan selection, speaking ability, delivery materials development, and effective time management in the classroom. This was supported by the result of CQ6, CQ7, CQ8, CQ9, and CQ10. The graph below shows the details of that result.

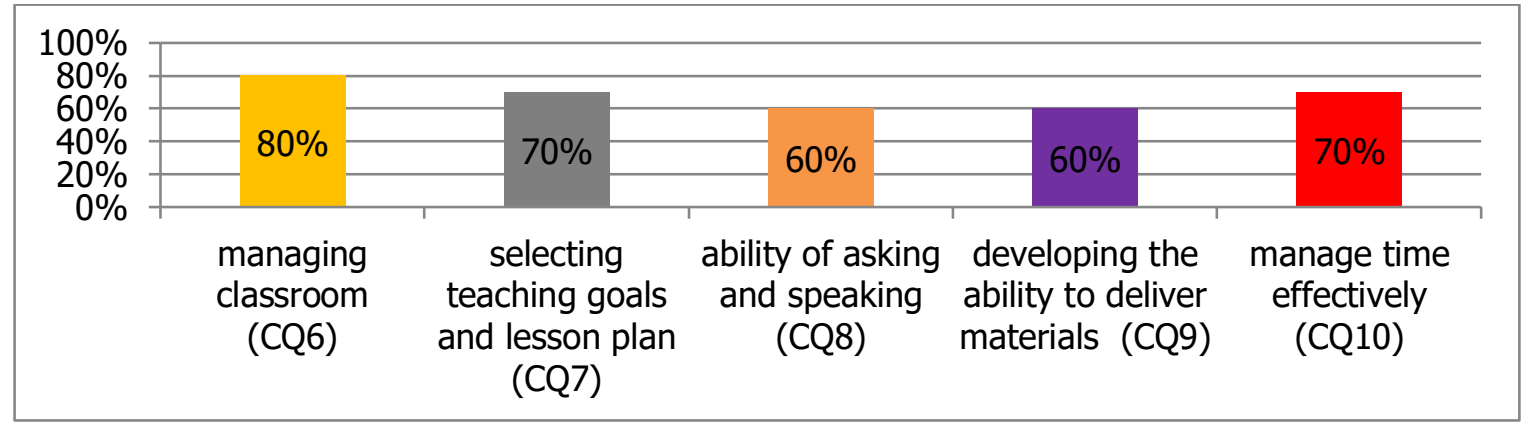

Figure 4 . The contribution of the microteaching test

Figure 4 above shows us that $80 \%$ of the respondents agreed that a microteaching test has a significant contribution to the students' overseas teaching practice in regards to classroom management. Classroom management is one of the vital components in teaching. It is defined as a teacher's strategies to make the process of teaching and learning keep effecetive (Ahmed et al., 2019). It is part of the teachers' efforts to have a good learning environment. Through microteaching, students found that they were trained to be able to manage the class well. This result is supported by previous researchers that students' classroom management was 
developed after doing a microteaching (Ahmed et al., 2019; Remesh, 2013; Thi \& Hoa, 2020). On the other hand, $70 \%$ of respondents stated that the microteaching test helped them in selecting teaching goals and lesson plans, and managing time effectively. From the activities of microteaching students may learn how to create teaching plans which are effective to be applied in the classroom (Soviyah, 2018). Furthermore, planning teaching activities is such essential in order to make the classroom activities managed well and all the set goals are achieved (Ahmed et al., 2019; Bakir, 2014; Uzun, 2012). They gain experience of setting time used for each activity. Meanwhile, $60 \%$ of respondents agreed that the microteaching test improved their speaking ability, as well as supporting their ability to deliver materials in the classroom. Since in microteaching they are supposed to speak English, it unconsciously made their English competence better. They could reduce their anxiety of speaking English and transferred the materials as well. Moreover, having this kind of improvement significantly help them in conducting their teaching practice as they have to use English as the language instruction in overseas teaching program. This condition was also found by Ismail (2011) that some students of English department were more confident in speaking English after joining microteaching.

All those findings were also supported by the data gained from a semi-structured interview. Here are some excerpts of the students' responses:

"Microteaching is our first step to face the real teaching practice. Microteaching give us illustration about the situation in the class and it can be used as our practice to solve the problem in the classroom to face the students that have different characteristic and how to treat them well. And also it can make me know how to manage the classroom."(R5)

"The microteaching test started with preparing the lesson plan, make or find the media that are related with the lesson plan. Then finding the teaching process appropriate for the lesson plan that we made before.t makes us ready in the real teaching."(R7)

"In the microteaching test there is a challenge to how I can improve my communication in the way I speak up with the students. The way on how I control the class to become conducive and pay attention to my lesson."(R6)

"it can improve my teaching and develop how I deliver my materials to the students." (R7)

"I can manage time properly and can manage the class effectively."(R8)

"Yes, the microteaching test provided practical exercises and has helped me improve my confidence to teach and talk louder in front of people around me, especially in the teaching classroom". (R2)

According to those evidence, it revealed that the microteaching test provided significant contribution to the students' overseas teaching practice. This microteaching helped them to do a teaching practice in the real classroom.

\section{Conclusion}

According to the data analysis, the researcher made a conclusion that the microteaching test 
influenced on English Department students' overseas teaching practice. There were good influences during the microteaching test which helped the students teacher to be more confident in doing their teaching practice, be better in the teaching learning, develop their teaching skills, as well as lower their anxiety and fear. It also encouraged the students teacher to be openminded to be creative in preparing their lesson. The miroteaching test contributed on English Department students' overseas teaching practice,such as to manage the classroom effectively, helping the students teacher preparation before doing their teaching practice, be fluent in delivering the materials to their students, and how to manage the students in the classroom. This study finding has revealed that the importance of microteaching test as the a factor influencing the students in practicing their teaching ability as well as developing their English skills. However, further studies are recommended to investigate more on the washback of the microteaching test specifically on students' English skills with the larger subjects. Gender issues also can be considered as the moderate variable to support the variaties of the research.

\section{References}

Abakay, U., Alincak, F., \& Demir, H. (2016). Effects of microteaching practices on pre-service physical education and sport teachers'attitudes towards teaching profession. European Journal of Education Studies.

Aglazor, G. (2017). The role of teaching practice in teacher education programmes: designing framework for best practice. Global Journal of Educational Research, 16(2), 101-110.

Ahmed, I., Shah, M. H., \& Tirmizi, S. R. (2019). Impact of microteaching training on prospective teachers' performance. WALIA Journal, 35(1), 33-38.

Ali, M., \& Hamid, M. O. (2020). Teaching English to the test: Why does negative washback xeist within secondary education in Bangladesh? Language Assessment Quarterly, 1-18. https://doi.org/10.1080/15434303.2020.1717495

Arsal, Z. (2015). The effects of microteaching on the critical thinking dispositions of pre-service teachers. Australian Journal of Teacher Education (Online), 40(3), 140.

Bakir, S. (2014). The effect of microteaching on the teaching skills of pre-service science teachers. Journal of Baltic Science Education, 13(6), 789-801.

Beikmahdavi, N. (2016). ashback in language testing: Review of related literature first. International Journal of Modern Language Teaching and Learning, 1(4), 130-136.

Brown, H. D. (2004). Language assessment: principles and classroom practices. Longman University Press. https://doi.org/10.2307/3588320

Caner, M. (2010). tudents views on using portfolio assessment in efl writing courses.

Cholis, H. W. N., \& Rizqi, F. (2018). Senior high school English teachers' perceptions on a highstakes test ( SBMPTN ): A washback study. International Journal of Education \& Literacy Studies, 6(2016), 47-52. https://doi.org/http://dx.doi.org/10.7575/aiac.ijels.v.6n.3p.47

Cohen, L., Manion, L., \& Morrison, K. (2007). Research method in education. Rutledge. 
Dhananjaya, S. Y., \& Nusrath, A. (2018). ffectiveness of a microteaching workshop designed to improve the teaching performance of post graduate medical students. International Journal of Research in Medical Sciences, 6(6).

Djurić, M. (2015). Dealing with situations of positive and negative washback. Scripta Manent, 4(1), 14-27.

Dong, M. (2020). Studies in Educational Evaluation Structural relationship between learners ' perceptions of a test, learning practices, and learning outcomes : A study on the washback mechanism of a high-stakes test. Studies in Educational Evaluation, 64(October 2019), 100824. https://doi.org/10.1016/j.stueduc.2019.100824

Fatonah, S., Suyata, P., \& Prasetyo, Z. K. (2013). No Title. Journal of Education and Practice, 4(13), 1-13. https://www.iiste.org/journals/

He, C., \& Yan, C. (2011). Exploring authenticity of microteaching in pre-service teacher education programmes. Teaching Education, 22(3), 291-302.

Hughes, A. (2003). Testing for language teachers. Ernst Klett Sprachen.

Hung, S. A., \& Huang, H. D. (2019). Standardized proficiency tests in a campus- wide English curriculum: A washback study. Language Testing in Asia, 9(21), 1-17. https://doi.org/https://doi.org/10.1186/s40468-019-0096-5

Ike, G. A. (2017). Historical development and traditional practices of the concept of microteaching and macroteaching and their major advantages. In In G. A. Ike. B. B. C. Onwuagboke, J. C. Anulobi and M. N. Ukegbu (Eds). Essential elements of Microteaching theory and practice. Owerri: Totan Publishers Ltd.

Indrawati, T. (2018). Washback of English national examination on teaching learning process. RETAIN, 6(3).

Ismail, S. A. A. (2011a). Student teachers' microteaching experiences in a preservice english teacher education program. Journal of Language Teaching and Research, 2(5), 1043-1051. https://doi.org/10.4304/jltr.2.5.1043- 1051

Ismail, S. A. A. (2011b). Student teachers' microteaching experiences in a preservice English teacher education program. Journal of Language Teaching and Research, 2(5).

Jabbarifar, M., Shameli-Sendi, A., \& Kemme, B. (2019). A scalable network-aware framework for cloud monitoring orchestration. Journal of Network and Computer Applications, 13(3), 1-14.

Katz, J. (2015). A theory of qualitative methodology: The social system of analytic fieldwork. Méthod (e) s: African Review of Social Sciences Methodology, 1(1-2), 131-146.

Kiggundu, E. M., \& Nayimuli, S. T. (2009). Teaching practice: A make or break phase for student teachers. South African Journal of Education, 29(3).

Kilic, A. (2010). Learner-centered micro teaching in teacher education. International Journal of Instruction, 3(1).

Kothari, C. R. (2004). Research methodology research \& techniques. New Age International, LTd.

Kuang, Q. (2020). A review of the washback of English language tests on classroom teaching. English Language Teaching, 13(9), 10-17. https://doi.org/10.5539/elt.v13n9p10 
Muñoz, R. (2017). The effect of washback on EFL learners' attitude towards tests. Studies in English Language Teaching, 5(3), 516-530.

Onwuagboke, B. B. C., Osuala, R. C., \& Nzeako, R. C. (2017). The impact of microteaching in developing teaching skills among pre-service teachers in Alvan Ikoku College of Education Owerri, Nigeria. An International Multi-Disciplinary Jounral, 11(2), 237-250. https://doi.org/http://dx.doi.org/10.4314/afrrev.v11i2.18

Ping, W. (2013). Micro-teaching: a powerful tool to embedding the English teacher certification testing in the development of English teaching methodologies. International Journal of English Language and Literature Studies, 2(3), 163-175.

Prastikawati, E. F., \& Asropah. (2020). Students' perception toward Spada Upgris as digital platform in learning process. REFLEKSI EDUKATIKA: Jurnal Ilmiah Kependidikan, 11(1). https://doi.org/https://doi.org/10.24176/re.v11i1.4768

Prastikawati, E. F., B, T. C. S., \& Sodiq, J. (2016). Portfolio Assess ment's impact on writing ability of English foreign language ( Efl ) learners. IOSR Journal of Research \& Method in Education (IOSR-JRME), 6(6), 11-18. https://doi.org/10.9790/7388-0606071118

Prastikawati, E. F., Wiyaka, W., \& Adi, A. P. K. (2020). Online backchannel as a formative assessment in improving writing skills. Journal on English as a Foreign Language, 10(2), 359384. https://doi.org/10.23971/jefl.v10i2.2044

Remesh, A. (2013). Microteaching, an efficient technique for learning effective teachin. Journal of Research in Medical Science, 18(2), 158-163.

Saban, A., \& Çoklar, A. N. (2013). Pre-service teachers' opinions about the micro-teaching method in teaching practise classes. Turkish Online Journal of Educational Technology-TOJET, 12(2).

Safa, M. A., \& Goodarzi, S. (2014). The washback effects of task-based assessment on the Iranian EFL learners' grammar development. Procedia - Social and Behavioral Sciences, 98, 90-99. https://doi.org/10.1016/j.sbspro.2014.03.393

Soviyah, S. (2018). Lesson study: What do pre-service teachers tell? Ahmad Dahlan Journal of English Studies, 5(1), 12. https://doi.org/10.26555/adjes.v5i1.8917

Sugiyono. (2015). Metode penelitian. Alfabeta.

Sukardi. (2003). Metodologi penelitian pendidikan kompetensi dan prakteknya. Bumi Aksara.

Sumardi, S. (2017). Performance-based assessment as a current trend in Elt: Investigating its washback effects on secondary-school students learning. Kajian Linguistik Dan Sastra, 2(1), 1. https://doi.org/10.23917/kls.v2i1.5347

Sundayana, W., Meekaeo, P., Purnawarman, P., \& Sukyadi, D. (2018). Washback of English national exams at ninth-grade level in Thailand and Indonesia. Indonesian Journal of Applied Linguistics, 8(1), 167-176.

Thi, D., \& Hoa, P. (2020). Washback of English proficiency test in classroom activities at National University of Arts Education. 36(1), 78-92.

Tirtaningrum, M., \& Ngadiman, A. (2015). Washback effect of the classroom test in junior high school. Magister Scientiae, 3(7), 41-52.

Uzun, N. (2012). A sample of microteaching in environmental education and its effect on 
preservice teachers' presenting effective lessons. Asia-Pacific Forum on Science Learning and Teaching, 3(1).

Wangchuk, S. (2019). Effects of microteaching on the pre-service teachers' teaching competence - A case in Bhutan. International Journal of Education and Development Using Information and Communication Technology, 15(1), 1-14.

Wiyaka, Prastikawati, E. F., \& Sodiq, J. (2016). Alternative assessments for reading in senior high school: A guide for classroom practices. Celt: A Journal of Culture, English Language Teaching \& Literature, 16(1), 49. https://doi.org/10.24167/celt.v16i1.565

Wiyaka, W., Prastikawati, E. F., \& Kusumo Adi, A. P. (2020). Higher-order thinking skills (hots)based formative assessment: A proposed model for language learning assessment. Vision: Journal for Language and Foreign Language Learning, 9(2), 115. https://doi.org/10.21580/vjv9i25859

Zhao, H. (2014). Investigating teacher-supported peer assessment for EFL writing. ELT Journal, $68(2), 155-168$. 